\title{
Eksistensi Lembaga Masyarakat Adat Mala Moi Dalam Pembagian Harta Warisan Tanah Adat Marga Osok Malaimsimsa Di Kota Sorong
}

\author{
Mulyadi Golap \\ Anisah Maya Djafar Umpain \\ Fakultas Hukum Universitas Muhammadiyah Sorong \\ Email : golapmulyadi@gmail.com \\ Email : anisahumpain@gmail.com
}

\begin{abstract}
Abstrak
Penelitian ini bertujuan untuk mengetahui Eksistensi Lembaga Masyarakat Adat Mala Moi dalam pembagian harta warisan tanah adat marga osok malaimsimsa di Sorong, dan untuk mengetahui pembagian harta warisan tanah adat pada suku moi marga Osok Malaimsimsa. Temuan yang diperoleh dari penelitian ini antara lain Eksistensi Lembaga Masyarakat Adat Mala Moi Sorong dalam menyelesaikan sengketa tanah adat, yaitu melaksanakan sidang adat berdasarkan laporan dari masyarakat adat, dan menjaga dan mengawal putusan sidang adat. Dan Pembagian harta warisan tanah adat pada suku moi marga Osok Malaimsimsa di Sorong, yaitu mengikuti hukum adat suku moi yang telah di wariskan oleh para leluhur suku Moi. Dalam hukum adat Suku Moi yang berhak mendapat pembagian harta warisan tanah adat ialah anak kandung laki-laki yang lahir dari pernikahan sah menurut adat dan pemberkatan digereja. Sementara dalam kondisi tertentu, ketika tidak ada anak laki-laki yang lahir dari pernikahan yang sah, maka anak perempuan dapat memiliki harta warisan milik ayahnya secara sah.
\end{abstract}

Kata Kunci : Eksistensi, Lembaga Masyarakat Adat Mala Moi, Warisan Tanah Adat, Marga Osok Malaimsimsa

\section{PENDAHULUAN}

Pembangunan dibidang hukum di Negara Indonesia lebih diarahkan kepada peningkatan dan upaya pembinaan penyempurnaan hukum nasional dengan memperhatikan kepada kesadaran hukum kepada masyarakat untuk mengakui Hukum Nasional, Hukum Adat, dan Hukum Agama serta menempatkan hukum sebagai pedoman tertinggi dalam kehidupan bernegara. Hal ini dapat tertera secara jelas dalam Undang-Undang Dasar Negara Republik Indonesia Tahun 1945 Pasal 18 b Ayat 2 yang berbunyi "Negara mengakui dan menghormati kesatuan - kesatuan masyarakat hukum adat beserta hak-hak tradisionalnya sepanjang masih hidup dan sesuai dengan perkembangan masyarakat, dan prinsip Negara Kesatuan Republik Indonesia yang diatur dalam Undang-Undang” .

Salah satu inti dari unsur-unsur hukum adat guna pembinaan hukum nasional adalah hukum waris adat. Untuk menemukan unsur-unsur dari hukum waris adat tersebut salah satunya dengan cara melakukan riset atau penelitian terhadap waris adat itu sendiri. Hal ini dimaksudkan untuk 
mengetahui persamaan dari berbagai sistem dan asas hukum waris adat yang terdapat di seluruh Nusantara ini yang jika ditarik benang merahnya dapat dijadikan titik temu dan kesamaannya dengan kesadaran hukum nasional sehingga apa yang dicita - citakan di dalam Undang-Undang Dasar Negara Republik Indonesia Tahun 1945 Pasal 18b Ayat (2) dapat diwujudkan dengan memberikan kewenangan kepada masyarakat adat untuk mengelola tanah adatnya, guna melindungi hak adat yang telah ada sebelum bangsa indonesia merdeka.

Hukum waris Adat yang berlaku di kalangan masyarakat Indonesia masih bersifat campuran, artinya ada yang tunduk kepada hukum waris dalam kitab Undang-Undang Hukum Perdata, Hukum Waris Adat dan ada yang tunduk pada Hukum Waris Islam. Khusus Hukum waris adat sebagaimana dianut oleh masyarakat adat maoi di sorong mempunyai corak kedaerahan dan memiliki sifat-sifat tersendiri yang tentunya berbeda dengan daerah-daerah lain di Indonesia, dan berbeda pula dengan hukum Islam maupun hukum Barat, dari sisi sistem yang diterapkan dalam pembagian waris adat berupa tanah adat maupun hal-hal lain. Dewasa ini tanah mempunyai arti dan peranan yang sangat penting bagi kehidupan manusia. Begitu pentingnya tanah bagi kehidupan manusia, maka setiap orang akan selalu berusaha memiliki dan menguasainya. Dengan adanya hal tersebut maka dapat menimbulkan suatu sengketa tanah di dalam masyarakat.

Ketentuan mengenai tanah dapat kita lihat dalam Undang-Undang Republik Indonesia Nomor 5 Tahun 1960 tentang Peraturan Dasar Pokok-Pokok Agraria atau yang biasa kita sebut dengan UUPA. Kedudukan Undang-Undang ini sangat penting, mengiingat tanah bagi kehidupan manusia, mengandung makna yang multidemensional. Pertama, dari sisi ekonomi, tanah merupakan sarana produksi yang dapat mendatangkan kesejahteraan. Kedua, secara politis, tanah dapat menetukan posisi seseoarang dalam pengambilan keputusan masyarakat. Ketiga, sebagai kapital budaya, dapat menetukan tinggi rendahnya status sosial pemiliknya. Keempat, tanah bermakna sakral, karena pada akhir hayat setiap orang akan kembali kepada tanah. Karena makna yang multidimensional tersebut ada kecenderungan, bahwa orang yang memiliki tanah atau mewarisinya akan mempertahankan tanahnya dengan cara apapun bila hak - haknya dilanggar.

Mencuatnya kasus-kasus tanah di Papua beberapa Waktu terakhir seakan kembali menegaskan kenyataan bahwa Pemerintah Pusat dan Pemerintah Daerah masih belum bisa memberikan jaminan hak atas tanah kepada rakyatnya. Sehingga eksistensi Undang-Undang Nomor 5 Tahun 1960 tentang Pokok-Pokok Agraria, dalam ruang Tanah Adat baru sebatas menandai dimulainya era baru kepemilikan tanah yang awalnya bersifat komunal berkembang 
menjadi kepemilikan individu dan kepemilikan adat oleh masyarakat adat, yang didapat dari warisan adat bersifat turun-temurun berdasarkan keret (Fam / Marga) dari garis Patrinial (Fam / Marga dari keturunan ayah). Sengketa tanah adat yang dikuasai karena warisan dalam garis keturunan patrinial yang terjadi di papua khususnya pada suku moi yang mendiami Kota Sorong dan Kabupaten Sorong, cenderung dikarenakan pengusaan penuh diwariskan pada anak laki-laki yang mengikuti dan mewarisi marga sang ayah kelak, hal ini mengundang konflik antar saudara.

Kedudukan Lembaga adat Mala Moi di Kota Sorong merupakan wadah adat sebagai pengejawatan dari Undang-Undang Republik Indonesia Nomor 21 Tahun 2001 tentang Otonomi Khusus bagi Papua, yang memiliki wewenang mengurus permasalahan adat, menjaga kelestarian adat serta mengangkat harkat dan martabat masyarakat adat di Tanah Papua. Secara de fakto, eksistensi lembaga Adat di Tanah Papua telah ada jauh sebelum lahirnya Undang-Undang Nomor 21 Tahun 2001 tentang Otonomi bagi Papua, namun belum memiliki andil yang signifikan dalam menata pranata kehidupan masyarakat adat.Menurut Supardi Danosehe, disebutkan bahwa "Lembaga adat di Papua telah ada sebelum Papau bergabung dengan Negara Kesatuan Republik Indonesia pada Tahun 1965. Tepatnya pada zaman kesultanan di Maluku Utara. Pada masa itu Papua merupakan daerah bawahan kesultanan Tidore di Maluku Utara”.

Sebagai wadah masyarakat yang telah terbentuk oleh sejarah yang panjang, peran lembaga adat dalam masyarakat memiliki pola dan pendekatan tersendiri. Demikian juga halnya dalam menyelesaikan masalah-masalah sosial yang terjadi di masyarakat, lembaga adat telah memiliki pola dan pendekatan tersendiri yang telah diakui oleh pemerintah Republik Indonesia sebagai salah satu altematif penyelesaian konflik di tengah-tengah masyarakat. Kendati demikian masyarakat adat menilai bahwa secara realistis eksistensi Lembaga Adat Mala Moi Sorong belum dapat menyelesaikan setiap masalah yang dihadapi oleh masyarakat adat secara arif dan bijaksana. Hal kongkrit ini, terlihat dalam sengketa perebutan warisan tanah adat antara Orpa Osok dan Frits Osok atas tanah warisan sang ayah, yang hingga kini belum terdapat solusi untuk menyelesaikan pertikaian antara dua orang saudara kandung ini.

Keterikatan antara orang dengan tanah kini menjadi sangat kompleks dengan berbagai dimensinya, sehingga setiap proses yang menyangkut kepemilikan warisan tanah adat harus ditempatkan secara seimbang mengikuti kaidah hukum adat yang telah menjadi ketentuan dalam masyarakat adat itu sendiri, sehingga ada kepastian kepemilikan terhadap warisan tanah adat dan mempersempit ruang konflik saudara yang timbul diatas tanah warisan orang tua. Guna 
memaksimalisasi hasil dalam implementasi, maka Lembaga Adat Mala Moi Sorong harus segera mengambil sikap, untuk menyelesaikan sederetan masalah yang terjadi diatas warisan tanah adat, sehingga kepentingan Pewaris Tanah Adat untuk menguasai warisan yang diwariskan padanya dan kepentingan Hukum Warga masyarakat yang kelak akan membelinya dari pemilik hak terhadap tanah adat tersebut. Dapat terlaksana dan terjamin dengan baik dan benar sesuai kaidah hukum adat yang berlaku dalam suku Moi.

\section{PEMBAHASAN}

\section{Eksistensi Lembaga Masyarakat Adat Mala Moi Sorong dalam menyelesaikan sengketa tanah adat}

Masyarakat adat suku Moi yang memiliki Hak Ulayat di Sorong membentuk Lembaga Masyarakat Adat Mala Moi sebagai Lembaga Kulture yang diberikan wewenang untuk mengurus segala permasalahan yang berkaitan dengan adat suku Moi, termasuk didalamnya yakni menyelesaikan sengketa tanah adat yang timbul akibat pertikaian antara saudara atau marga yang terdapat dalam rumpun suku Moi di wilayah hukum adat. Bagi bangsa masyarakat adat Suku Moi tanah adalah karunia Tuhan Yang Maha Esa dan merupakan kekayaan adat yang diwariskan oleh leluhur. Sebagai modal dasar kekayaan adat, tanah mempunyai karakteristik yang unik, yaitu multidimensional, multisektoral dan multidisiplin. Oleh karena itu perlu dikelola secara cermat pada masa sekarang maupun untuk masa yang akan datang.

Perkembangan ilmu pengetahuan dan teknologi telah memberikan konsekuensi bahwa hubungan antara manusia dengan tanah mutlak diperlukan adanya penataan dan pengaturan yang lebih seksama, khususnya yang berkenaan dengan penguasaan, peruntukan dan penggunaan, persediaan dan pemeliharaannya. Tanah sebagai salah satu kebutuhan dalam penyelenggaraan hidup manusia memiliki peranan yang sangat vital. Masyarakat yang bercorak hidup agraris menggantungkan hidup sepenuhnya pada tanah, dana merupakan objek utama yang harus dimiliki dalam penyelenggaraan kehidupan agraria baik yang berbentuk pengadaan lahan pertanian maupun perkebunan. Tanah juga menjadi landasan tolak ukur kesejahteraan dan kemakmuran bagi masyarakat adat yang berdomisili di wilayah hukum adat. Oleh karena itu, maka untuk menjaga warisan leluhur masyarakat adat moi, maka penting eksistensi wewenang dari Lembaga Masyarakat Adat Mala Moi sorong, guna menyelesaikan berbagai sengeta tanah adat. Adapun wewenang sebagaiman hasil penelitian, dapat diuraiakan sebagai berikut : 


\section{Melaksanakan Sidang Adat berdasarkan Laporan dari Masyarakat Adat}

Hukum adat sebagai pelengkap mempunyai arti, yaitu bahwa pembentukan hukum nasional yang mewujudkan kesatuan hukum, kepastian hukum, perlindungan hukum kepadampemegang hak memerlukan suatu proses yang memakan waktu. Selama proses itu belum selesai, hukum tertulis yang sudah ada tetapi belum lengkap, maka memerlukan pelengkap agar tidak terjadi kekosongan hukum. Pemberian kedudukan hukum adat sebagai dasar pembentukan UUPA pada hakekatya adalah merupakan pengakuan terhadap eksistensi hukum adat yaitu berupa Pengakuan dan penegasan sebagai dasar hukum berlakunya hukum adat, dan Pengakuan terhadap Hukumhukum adat merupakan posisi dasar berlakunya hukum adat. Hukum adat yang dimaksudkan UUPA adalah hukum adat hukum aslinya golongan rakyat pribumi yang merupakan hukum yang hidup dalam bentuk tidak tertulis dan mengandung unsur-unsur nasional yang asli, yaitu sifat kemasyarakatan dan kekeluargaan yang berdasarkan keseimbangan serta diliputi oleh suasana keagamaan atau prinsip nasionalitas. Sehingga pembatasan-pembatasan bagi berlakunya hukum adat tidaklah mengurangi arti ketentuan pokok dalam UUPA, bahwa hukum Agraria memakai hukum adat sebagai dasar dan sumber utama pembangunannya. Pengakuan hukum adat merupakan perlindungan hukum masyarakat adat. Pengakuan hukum adat sebagaimana disebutkan dalam pasal 5 UUPA merupakan suatu bentuk keragu-raguan, terutama mengenai kemampuan hukum adat dalam memenuhi tuntutan masyarakat modern. Hal ini terutama dilontarkan oleh penganut paham kodifikasi yang intinya hukum adat tidak menjamin kepastian hukum. Namun pada kenyataanya justru hukum adat merupakan metode yang sangat efektif menyelesaikan sengketa tanah yang terjadi antara masyarakat adat, yakni melalui sidang adat.

Sidang adat dalam hukum adat suku moi mempunyai muatan mistis sehingga memiliki keunggulan yakni dapat menyelesaikan permasalahan yang terjadi dalam masyarakat adat secara menyeluruh, cepat, mudah dan sederhana. Hukum adat juga mempunyai keunggulan dapat mengantisipasai konflik etnik yang muncul dalam masyarakat. Hal ini disebabkan pada sebuah kenyataan bahwa hukum adat masih dipatuhi oleh sebagian besar masyarakat adat, sehingga pemerintah Kota Sorong mendorong untuk memperdayakan masyarakat adat, menumbuhkan prakarsa dan kreativitas penyelesaian permasalahan-permasalahan yang muncul ditengah masyarakat dengan menggunakan nilai-nilai kearifan lokal atau kearifan hukum adat yaitu melalui sidang adat. Dengan demikian peran dan fungsi Lembaga Adat dalam menyelesaikan sengketa tanah adat yang sering terjadi di Kota Sorong akan lebih efektif. 
Hukum tanah merupakan hukum positif Negara Indonesia yang mengatur tentang pertanahan di Indonesia, yang dalam penerapannya akan mencapai tujuannya jika memenuhi 3 aspek, yakni (1) Aspek yang bernilai filosofis berartikan bahwa hukum itu harus berdasarkan pada pancasila. (2) Aspek yang bernilai yuridis memiliki arti bahwa hukum itu diatur dalam bentuk suatu peraturan perundang-undangan untuk mencapai kepastian hukum. (3) Aspek yang bernilai sosiologis memiliki arti bahwa hukum itu harus mengandung nilai-nilai yang ada dalam masyarakat agar suatu hukum itu dapat diterima oleh masyarakat. Berkaitan dengan aspek sosiologis tersebut, maka dalam pembuatan UUPA dibutuhkan hukum adat yang merupakan hukum asli masyarakat Indonesia. Hukum adat dibutuhkan,karena dapat memberikan sumbangan bagi pemikiran Hukum Tanah di Indonesia. Jadi dalam pembentukan Hukum Tanah di Indonesia, tidak mengabaikan keberadaan hukum Adat.

Tahapan perkembangan hukum adat di Indonesia sedang berada pada posisi dilema untuk kelangsungannya. Sebagai Negara yang sedang melakukan transformasi hukum menuju pada sistem hukum tertulis, Indonesia saat ini sedang mengupayakan suatu proses unifikasi dari berbagai sistem hukum tidak tertulisnya yang terdapat dan berlaku dibeberapa bagian masyarakat di Indonesia. Salah satu pokok perhatian dalam proses tersebut yaitu mengenai keberadaan hukum adat terutama untuk bidang-bidang yang sensitif seperti sidang adat. Bidang-bidang hukum adat yang sampai sekarang masih hidup dalam pola-pola hubungan hukum pada masyarakat di Indonesia, keberadaannya sangat tergantung pada budaya dan keyakinan masyarakatnya. Untuk kepentingan elaborasi bidang-bidang hukum adat yang masih berlaku di Indonesia, sangat perlu dilakukan diperhatikan persesuaian antara putusan sidang adat dan sidang pengadilan. Pilihan terhadap putusan pengadilan karena berbagai alasan yang berkembang dalam wacana hukum adat sehingga putusan pengadilan merupakan sesuatu yang penting dalam fungsinya sebagai pembentuk hukum, sehingga terkadang justru mengabaikan putusan pada sidang pengadilan adat. Kondisi ini yang kemudian menjadi dikusi dalam masyarakat adat suku Moi Sorong.

Secara keahlian dalam hukum adat para tua-tua adat yang menyelengarakan sidang adat, telah melewati pendidikan adat (kambik) yang dilaksanakan secara turun-temurun di rumah adat oleh suku Moi yang ada di Kabupaten Sorong sebelum datangnya pengaruh agama besar dari luar Papua. Pada masa itu masyarakat moi masih menganut animisme. Semua kegiatan kemasyarakatan selalu dihubungkan dengan roh dan arwah leluhur. Setelah mendapat pengaruh agama Islam dan Kristen maka pendidikan adat sudah tidak lagi memasukkan unsur animisme. Kambik 
mengajarkan pengetahuan unsur-unsur alam berdasarkan gejala alam yang terdapat di sekitar kehidupannya. Pengetahuan yang diajarkan dalam pendidikan adat adalah mengenai segala hal yang menyangkut kehidupan yaitu: sistem perkawinan, sistem pembagian harta, sistem adat dalam mengatur perempuan suku Moi, sistem adat dalam hak ulayat tanah, sistem pembayaran adat bagi yang meninggal, sistem pendidikan, sistem bercocok tanam, sistem pengobatan, dan sistem marga dengan daerah-daerah keramat.

Keberadaan pendidikan adat tersebut membentuk peradaban yang lebih maju. Para alumni dari pendidikan adat telah dipersiapkan untuk menjadi pemimpin yang tahu segala hal mengenai adat. Mereka menyusun aturan-aturan yang harus dijalankan dan dipatuhi oleh masyarakat Adat suku Moi. Pada hakekatnya masyarakat Moi sejak zaman dahulu sudah menyadari tentang hukum dan aturan dalam kehidupan bermasyarakat, berbangsa, dan bernegara. Mereka juga menyadari pentingnya keseimbangan lingkungan alam yang berdampak terhadap kehidupan manusia antara baik dan buruk. Namun dalam berjalannya dari waktu ke waktu, nilai-nilai luhur kearifan lokal dalam budaya Kambik tersebut mulai meredup, memudar, hilang, dan tenggelam. Lalu yang tertinggal hanya nama dan kenangan semata yang menjadi simbol tanpa arti. Bahkan akhir-akhir ini budaya masyarakat hampir secara keseluruhan mengalami reduksi, hanya menampakkan diri secara formalitas. Padahal keberadaan pendidikan adat tersebut sangat dibutuhkan oleh masyarakat suku Moi karena para alumni pendidikan adat yang disebut untelen tersebut dipersiapkan menjadi pemimpin adat dan dewan adat yang diharapkan mampu mengatasi permasalahan adat di tanah Malamoi.

\section{Menjaga dan Mengawal Putusan Sidang Adat}

Menjaga dan mengawal hasil dari sifang adat merupakan suatu instrument dalam menjaga kesatuan hasil dari ketetapan suat lembaga peradilan perdamaian antara para warga masyarakat hukum adat di lingkungan masyarakat hukum adat yang ada. Secara umum setiap manusia mempunyai kepentingan baik kepentingan kelompok maupun kepentingan individu, untuk memenuhi dan melindungi kepentingannya itu, menusia memerlukan manusia lain. Masyarakat merupakan kelompok atau kumpulan manusia atau makhluk sosial. Sudah menjadi sifat bawaanya bahwa manusia hanya dapat hidup dalam masyarakat. Kehidupan bersama di dalam suatu masyarakat menimbulkan interaksi, kontak satu sama lain, sehingga bentrokan atau konflik kepentingan antar sesama manusia tidak dapat dihindarkan. Konflik kepentingan itu terjadi apabila 
dalam melaksanakan atau mengejar kepentingannya seseorang merugikan orang lain. Untuk itu diperlukan suatu pedoman atau kaedah yang mengatur bagaimana manusia harus bertingkah laku di dalam masyarakat agar tidak merugikan orang lain dan dirinya sendiri.

Hukum adat suku moi merupakan salah satu bentuk hukum yang masih eksis dalam kehidupan masyarakat hukum adat di Papua dan masih sangat dijaga keberadaannya oleh masyarakat adat moi dan pemerintah daerah, sebab hukum Adat merupakan salah satu bentuk hukum yang berlaku dalam kehidupan dan budaya hukum masyarakat papua. Eksistensi hukum adatsuku moi dapat dilihat dengan adanya sekretariat Lembaga Masyarakat Adat (LMA) Mala Moi dan masih melekatnya budaya dalam aktivitas keseharian dari masyarakat suku moi, seperti dalam memutuskan sengketa tanah adat mengunakan sidang adat. Hukum adat tetap dipertahankan hingga saat ini oleh masyarakat hukum adat suku moi sebab mereka percaya bahwa putusan yang dikeluarkan melalui peradilan adat terhadap suatu permasalahan yang diadili melaluinya dapat memberikan kepuasan akan rasa keadilan, serta kembalinya keseimbangan dalam kehidupan masyarakat adat atas kegoncangan spiritual yang terjadi atas berlakunyap sengketa adat tersebut.

Guna mengukur tingkat efektifitas dari wewenang LMA Mala Moi dalam menyelesaikan sengketa tanah yaitu dengan menjaga dan mengawal hasil putusan sidang adat yang telah ditetapkan oleh tua-tua adat berdasarkan ritualisasi adat tersebut. Sakralnya putusan adat dalam sidang adat membuat masyarakat adat berharap agar hasil yang telah ditetapkan oleh tua-tua adat untuk dijaga dan dikawal berlakunya, mengingat ditengah berlakunya hukum adat juga terdapat hukum positif yang dibuat oleh Negara dan putusannya juga bersifat mengikat bagi seluruh warga Negara Indonesia, termasuk masyarakat adat. Dalam kondisi ini, tidak jarang ditemukan bahwa adanya pertentangan putusan antara hukum positif yang diputuskan melalui persidangan oleh majelis hakim, dan juga putusan sidang adat yang ditetapkan oleh para tua-tua melalui sidang adat. Situasi demikian membuat masyarakat, menitipkan harapan dengan memberikan wewenang pada LMA Mala Moi untuk menjaga dan mengawal setiap putusan yang telah dibuat oleh tua-tua adat dalam sidang adat. Untuk mengetahui langkah yang telah dilakukan LMA Mala Moi dalam hal ini, maka peneliti melakukan tanya jawab pada 37 (tiga puluh tujuh) Orang masyarakat Adat Moi atau Responden Penelitian yang mengetahui eksistensi LMA Mala Moi dalam mengimplementasikan wewenang tersebut. 


\section{Pembagian Harta Warisan Tanah Adat pada Suku Moi Marga Osok Malaimsimsa di Sorong}

Tanah mempunyai peran yang besar dalam dinamika pembangunan, maka di dalam UndangUndang Dasar Tahun 1945 Pasal 33 ayat 3 disebutkan bahwa bumi dan Air dan kekayaan alam yang terkandung didalamnya dikuasai oleh Negara dan dipergunakan untuk sebesar-besarnya kemakmuran rakyat. Ketentuan mengenai tanah juga dapat kita lihat dalam Undang-Undang Republik Indonesia Nomor 5 Tahun 1960 tentang Peraturan Dasar Pokok-Pokok Agraria atau yang biasa kita sebut dengan UUPA. Hal ini mengingat tanah bagi kehidupan manusia, mengandung makna yang multidemensional. Pertama, dari sisi ekonomi, tanah merupakan sarana produksi yang dapat mendatangkan kesejahteraan. Kedua, secara politis, tanah dapat menetukan posisi seseoarang dalam pengambilan keputusan masyarakat. Ketiga, sebagai kapital budaya, dapat menetukan tinggi rendahnya status sosial pemiliknya. Keempat, tanah bermakna sakral, karena pada akhir hayat setiap orang akan kembali kepada tanah. Karena makna yang multidimensional tersebut ada kecenderungan, bahwa orang yang memiliki tanah akan mempertahankan tanahnya dengan cara apapun bila hak-haknya dilanggar.

Dalam hukum adat suku moi kepemilikan tanah adat merupakan sesuatu benda atau harta yang dimiliki sejak turun-temurun atau merupakan warisan yang diberikan oleh generasi selanjutnya, sehingga sistem pembagian dan atau penguasaanya di atur menurut hukum adat sukun moi. Begitupun dengan pembagian harta warisan tanah adat milik marga Osok Malaimsimsa yang berada di Distrik Sorong Utara atau tepatnya di Malanu Kampung dan disebagian jalan Alteri, juga dilakukan menurut hukum adat suku moi. Dalam proses pembagian tanah adat suku moi, yang memiliki hak ialah anak yang lahir dari perkawinan yang sah, baik secara adat maupun agama. Anak tersebut berhak atas tanah yang diwariskan oleh orang tuanya. Untuk anak perempuan hanya memiliki hak makan waris atau dapat mengambil hasil dari tanaman yang berada diatas tanah waris, namun tidak memiliki hak untuk menguasai tanah tersebut. Hal ini dapat berbalik apabila anak perempuan ialah anak tunggal atau semua anak dalam keluarga tersebut perempuan, maka anak perempuan yang kedudukannya hanya makan waris saja dapat memiliki harta warisan.

Harta Warisan Tanah Adat pada Suku Moi Marga Osok Malaimsimsa di Sorong dilakukan dengan menggunakan ketentuan yang diatur dalam hukum adat suku moi, dimana kepemilikan tanah tersebut dimiliki oleh anak tunggal yang lahir berdasarkan ritualisasi dalam perkawinan adat dan agama yang sah, dengan demikian maka kepemilikan yang sah berdasarkan hukum adat ialah 
Orpa Osok yang merupakan anak tunggal dari perkawinan yang sah antara Almarhum Agustinus Osok dan Fransina Mobilala. Sementara Frits Osok lahir dari ibu yang menurut hukum adat tidak sah, sehingga tidak berhak mendapatkan warisan tanah adat yang ditinggalkan oleh Almarhum Agustinus Osok. Dalam pembagian haarta warisan adat marga Osok Malaimsimsa, tua-tua adat berpandangan bahwa Frits Osok tidak berhak mendapat hak warisan adat walaupun dia anak tunggal dari pasangan Almarhum Agustinus Osok dan Almarhuma Engelina Kalawaisa, karena lahir tidak melalui hubungan yang sah berdasarkan ritualisasi pernikahan adat dan Agama, sehingga tidak tinggal serumah.

Hubungan Almarhum Agustinus Osok dan Ibunda Frits Osok sampai saat ini masih misteri, sebab kondisinya yang mengalami gangguan jiwa yang kemudian tiba-tiba hamil diluar nikah dan menurut cerita yang berkembang dimasyarakat adat Moi belum dapat dipastikan siapa yang menghamili almarhuma Ibunda Frits Osok, namun berdasarkan sidang gereja Almarhum Agustinus Osok mengakui bahwa telah terjadi hubungan badan antara keduanya. Berbeda dengan Almarhuma Fransina Mobilala yang dinikahi melalui ritualisasi yang sah, dan dari pernikahan adat dan gereja tersebut lahirlah Orpa Osok yang juga merupakan anak tunggal. Berdasarkan dalil sejarah maka dalam pembagian harta warisan adat, para tua-tua adat suku moi dalam sidang adat menetapkan bahwa harta warisan adat milik Almarhum Agustinus Osok sah milik Orpa Osok. Dalam hukum adat suku moi, belum sahnya pernikahan adat antara Almarhum Agustinus Osok dan Ibunda Frits Osok, berdampak terhadap penggunaan Marga yang digunakan oleh Frits Osok. Secara adat Frits tidak diperbolehkan menggunakan marga Osok karena keluarga Osok Malaimsa belum membayar adat pada keluarga Kalawaisa, sehingga untuk mengunakan marga Osok, maka keluarga Osok harus membayar adat pada keluarga Kalawaisa, dengan begitu Frits baru bisa mengunakan marga Osok, dan proses bayar adat tersebut harus dilakukan oleh Orpa Osok selaku kakak Tiri.

Dalam adat moi anak perempuan hanya memiliki hak sebagai makan waris tetapi tidak dapat memiliki hak untuk menjadi pewaris. Kondisi ini akan berbalik apabila tidak terdapat anak lakilaki dalam keturunan tersebut, semuanya anak perempuan atau hanya perempuan tunggal dari sebuah perkawinan yang sah berdasarkan hukum adat, gereja, dan Negara. Maka anak perempuan dapat menjadi pewaris dari tanah warisan adat tersebut. Ketentuan untuk mewariskan tanah adat yang dikuasai oleh perempuan ke pewaris selanjutnya, dapat dilakukan dengan dua cara, yaitu : (1) Dengan pengambilan darah. Proses ini dilakukan dengan menyatukan darah anak yang telah 
dipilih dengan ibunya. Darah diambil dengan bambu adat dan selanjutnya disatukan dengan ritual adat, sketika itu maka anak tersebut akan mengunakan marga dari ibunya, atau marga dari kakeknya yang mewariskan tanah adat kepada ibunya tersebut. (2) Warisan yang turun secara langsung. Proses ini terjadi secara langsung yakni anak laki-laki yang lebih tertua dalam keturunan tersebut mendapatkan harta warisan ibunya yang ditingalkan kakeknya selaku pewaris sebelumnya, tanpa harus mengganti marganya. (3) Apabila Anak perempuan si pewaris tidak memiliki anak atau tidak menikah, maka hak waris tersebut dapat ia wariskan kelak pada anak yang di angkatnya melalui upacara adat penyatuan darah. Dimana anak yang diangkat disatukan darahnya dengan ibu angkatnya, dan seketika itu juga si anak angkat tersebut akan mengikuti marga ibu angkatnya, dan selanjutnya secara adat ia sah menjadi pewaris harta warisan yang dimiliki ibu angkatnya.

Tanah memiliki arti yang sangat penting bagi setiap individu dalam masyarakat. Selain memiliki nilai ekonomis yang dapat dicadangkan sebagai sumber pendukung kehidupan manusia di masa mendatang, tanah juga mengandung aspek spiritual dalam lingkungan dan kelangsungan hidupnya. Tanah merupakan tempat pemukiman, tempat melakukan kegiatan manusia bahkan sesudah matipun masih memerlukan tanah. Bagi mayoritas manusia, memiliki tanah seperti halnya makan nasi atau bahan pangan yang mengandung karbohidrat merupakan suatu keniscayaan dan kebutuhan. Memiliki tanah terkait dengan harga diri (nilai sosial), sumber pendapatan (nilai ekonomi), kekuasaan dan hak previlise (nilai politik), dan tempat untuk memuja Sang Pencipta (nilai sakral-budaya). Tidak mempunyai tanah berarti kehilangan harga diri, sumber hidup, kekuasaan, dan tempat penghubung antara manusia dengan Sang Pencipta. Oleh karenanya, setiap orang berjuang untuk memiliki tanah dan mempertahankannya. Perjuangan tersebut disertai tekad bulat untuk mengorbankan nyawa daripada menanggung malu atau kehilangan harga karena tidak punya tanah. Bagi sebuah negara, tanah merupakan salah satu modal dalam pembangunan yaitu menjadi faktor produksi yang digunakan untuk menghasilkan komoditi-komoditi perdagangan. Sedemikian pentingnya arti tanah bagi manusia, sehingga masyarakat adat suku moi memandang penting untuk menguasainya dengan melakukan pembagiannya yang sesuai dengan hukum adat, sebab hukum adat melihat kepemilikan sah berdarkan berbagai aspek, mulai dari sistem pernikahan, kematian hingga kelahiran pemilih hak atas tanah adat.

bahwa dalam pembagian harta warisan adat pada suku Moi Marga Osok Malaimsimsa di Sorong dilaksanakan berdasarkan ketentuan hukum adat, dimana anak yang sah berdasarkan 
ketentuan adat menjadi pemilik dari warisan adat. Ketentuan adat ini telah ada dari jaman dahulu atau merupakan tradisi leluhur yang secara turun-temurun di pertahankan oleh masyarakat adat suku Moi di Sorong dan telah menjadi hukum adat, kendati demikian dalam pelaksanaannya belum dapat menjadi satu-satunya solusi untuk menyelesaikan berbagai permasalahan terkait tanah adat antara saudara ataupun marga di Sorong. Keterikatan antara orang dengan tanah yang dimiliki, menjadi sangat kompleks dengan berbagai dimensinya, sehingga proses penguasaan tanah adat tanpa adanya unsur kerelaan dari pemegang hak akan menimbulkan banyak masalah di atas tanah adat, persoalan ini menyangkut dua dimensi yang harus ditempatkan secara seimbang yaitu kepentingan adat dan kepentingan pembangunan daerah. Bilamana hal tersebut tidak diindahkan akan timbul persoalan-persoalan yang bisa memicu terjadinya sengketa.

Mencuatnya kasus-kasus sengketa tanah pada masyarakat adat Moi, seakan menegaskan kenyataan bahwa kesadaran masyarakat adat terhadap hukum adat mulai menyusut, disisi lain belum maksimalnya peran Lembaga Masyarakat Adat Suku Moi Sorong dalam memberikan jaminan hak atas tanah kepada rakyatnya. Sementara Undang-Undang Republik Indonesia Nomor 5 Tahun 1960 tantang Undang-Undang Pokok Agraria (UUPA) baru sebatas menandai dimulainya era baru kepemilikan tanah yang awalnya bersifat komunal berkembang menjadi kepemilikan individu setiap marga dalam masyarakat adat. Berbagai kasus yang menyangkut sengketa di bidang pertanahan tidak pernah surut. Bahkan di berbagai marga dalam suku Moi mempunyai kecenderungan meningkat yang disebabkan berbagai kepentingan yang saling tumpang tindih dari berbagai aspek kemasyarakatan meliputi bidang ekonomi, sosial, dan politik. Berbagai peristiwa yang terjadi di tengah masyarakat cenderung adanya penuntutan hak dimana mereka para pemilik hak di atas Tanah Adat akan selalu mempertahankan hak-haknya, disisi lain peran pemerintah juga harus menjalankan kepentingan demi terselenggaranya kesejahteraan umum bagi seluruh warga masyarakat sehingga kadang kala terjadi benturan kepentingan dari masing-masing pihak. Kondisi ini akan semakin rumit apabila benturan yang terjadi antara sesama masyarakat adat, yang disebabkan pembagian harta warisan tanah adat tersebut dirasa belum memenuhi unsur keadilan, akibatnya pembangunan yang terjadi di atas tanah tersebut akan terhenti.

Guna menilai objektifitas dari sistem dan proses pembagian tanah warisan adat marga Osok Malaimsimsa berjalan sebagaimana yang ditentukan oleh hukum adat suku Moi, sehingga dapat menepis persepsi sebagian masyarakat adat Moi yang menyatakan bahwa kepemilikan tanah adat dari Almarhum Agustinus Osok yang jatuh ditangan Orpa Osok tidak sesuai dengan hukum adat 
yang diwariskan oleh para leluhur Suku Moi, sebab perempuan dalam hukum adat suku Moi tidak berhak menjadi ahli waris apabila masih ada saudara laki-laki, karena secara tidak langsung akan menghilangkan status marga tanah warisan adat tersebut. Secara umum pandangan ini menjadi dasar penolakan kepemilikan harta warisan adat marga Osok Malaimsimsa yang saat ini masih terdapat sengketa didalamnya. Penolakan yang kepemilikan harta warisan adat yang dilakukan oleh Frits Osok terhadap Kakak tirinya yang bernama Orpa Osok, mengindentifikasikan bahwa harus ada pelurusan dalam kepemilikan berdasarkan adat. Frits Osok berangapan bahwa pengakuan yang dilakukan oleh Ayahnya Almarhum Agustinus Osok dalam sidang yang terjadi pada gereja, membuktikan bahwa secara biologis dia adalah anak yang sah, sehingga sebagai anak laki-laki tunggal, maka dia berhak sepenuhnya terhadap harta warisan yang ditingalkan ayahnya tersebut, sebab menurut adat suku Moi yang memiliki hak atas warisan tanah adat ialah anak lakilaki bukannya anak perempuan, sehingga sudah selayaknya harta tersebut jatuh pada Frits Osok. Bertolak dari pemahaman ini, maka penting untuk dilakukan penelitian lebih dalam terkait hal ini, sehingga peneliti melakukan tanya jawab pada 45 (empat puluh lima) Orang masyarakat Adat Suku Moi atau Responden Penelitian yang memahami pembagian tanah warisan adat dalam hukum adat suku Moi di Sorong.

\section{SIMPULAN}

Bahwa eksistensi Lembaga Masyarakat Adat Mala Moi Sorong dalam menyelesaikan sengketa tanah adat. Melaksanakan Sidang Adat berdasarkan Laporan dari Masyarakat Adat. Pelaksanaan sidang adat dilakukan oleh tua-tua adat suku Moi ditempat yang telah ditentukan untuknya, dan tempat tersebut telah ditetapkan oleh para leluhur untuk melaksanakan sidang adat, Menjaga dan Mengawal Putusan Sidang Adat.

Pembagian harta warisan tanah adat pada suku moi marga Osok Malaimsimsa di Sorong, yaitu mengikuti hukum adat suku moi yang telah di wariskan oleh para leluhur suku Moi. Dalam hukum adat Suku Moi yang berhak mendapat pembagian harta warisan tanah adat ialah anak kandung laki-laki yang lahir dari pernikahan sah menurut adat dan pemberkatan digereja. Sementara dalam kondisi tertentu, ketika tidak ada anak laki-laki yang lahir dari pernikahan yang sah, maka anak perempuan dapat memiliki harta warisan milik ayahnya secara sah. 


\section{DAFTAR PUSTAKA}

Ahmad Syamsul Budhory, 2003. Rekaya Sengketa dalam perhelatan Pertanahan Nasional. Bumi Aksara, Jakarta.

A.G Pringgodigdo, 2014. Pertumbuhan dan Perkembangan Kota-Kota Muslim di Indonesia dari Abad Ke XIII sampai Abad Ke XVIII Masehi. Grafitri Budi Utami, Bandung.

Andre sitanggang, 2014. Kedudukan Lembaga Adat dalam sengketa Masyarakat Adat (dikodifikasi berdasarkan penelitian pada masyarakat adat Wamena Tahun 2013). CV Siantar Pustaka, Medan.

A.P Parlindungan, 1995. Luas Tanah Sebagai Indikator Pembangunan Infrastruktur. Andi, Yogyakarta.

Arman Hidayat, 2012. Pengantar Hukum Adat. Cahaya Atma Pustaka, Yogyakarta.

Berzelius, 2012.Testur Tanah Pertanian. Airlangga Perss, Jakarta.

Budiman Tanuredjo, 2009. Rekonstruksi Membangun Kota Mandiri. Papas Sinar Sinanti, Depok Timur.

C.S.T Kansil, 2007. Pengantar Ilmu Hukum (edisi kedua). Sinar Grafika, Jakarta.

Demianus Antoh, 2010. Eksistensi Lembaga Adat dalam Wajah Otsus Papua. PT. Pustaka Cempaka Emas, Jakarta Pusat.

Demianus Antoh, 201. Transformasi Kebudayaan Papua. Gramedia, Jakarta.

D. Oktora, 2009. Masyarakat Adat Indonesia. PT Gramedia Indonesia, Jakarta.

Eman Suparman, 2011. Hukum Waris Indonesia. PT Refika Aditama, Bandung.

Hadi Sutrisno, 2009. Metodelogi Penelitian Kualitatif. Cipta Pustaka. Bogor.

Hasibuan, 2009. Wewenang dan Implikasinya. Intan Pustaka, Serang.

Hilman Hadikusuma, 2011. Teori Hukum dan Adat (Jilid II). Graha Cita Nusantara, Bandung.

Hondari Nawawi, 2007. Metode Penelitian Ilmiah. Airlangga Perss, Jakarta.

I Gede Pantjaastawat, 2009. Rekonstruksi Membangun Kota Mandiri. Gunung Mulia, Jakarta.

Jalaluddin Tunsam, 2013. Adat dan Masyarakat. Rahmat Pustaka, Tangerang. 